\title{
Islam dan Perkembangan Bahasa Melayu
}

Ening Herniti

Fakultas Adab dan Humaniora UIN Yogyakarta ening.herniti@uin-suka.ac.id

\begin{abstract}
The spread of Islam in Nusantara has not only influenced social change, but also in language development. One of the languages used in Nusantara at that time was the Malay language. Malay as lingua franca has an important role in communication between traders in the Malacca Strait. Arabic also serves as a lingua franca especially in the spread of Islam. Arabic and Malay have the same position, namely as lingua franca, causing language contact. This language contact represents a balance of two languages resulting in language borrowing. This research is libraryresearch with qualitative-descriptive method. This paper describes the influence of the spread of Islam in Nusantara to the development of Malay (Bahasa). The conclusion of this study shows that the spread of Islam in Nusantara influences the system alphabet (alphabet Jawi), the form of loanword, the domain of loanword, and Arabic-Latin transliteration.
\end{abstract}

Keywords: The spread of Islam; influence; contact language; lingua franca; loanword

\begin{abstract}
Abstrak
Penyebaran agama Islam di Nusantara tidak hanya berpengaruh pada perubahan sosial, tetapi juga pada perkembangan bahasa. Salah satu bahasa yang digunakan di wilayah Nusantara pada saat itu adalah bahasa Melayu, yang kemudian menjadi bahasa Indonesia. Bahasa Melayu sebagai lingua franca memiliki peranan penting dalam memperlancar komunikasi antarpedagang di Selat Malaka. Bahasa Arab juga berperan sebagai lingua franca terutama dalam penyebaran agama Islam. Bahasa Arab dan bahasa Melayu memiliki kedudukan yang sama, yakni sebagai lingua franca sehingga menimbulkan kontak bahasa. Peristiwa kontak bahasa ini mepresentasikan adanya keseimbangan dua bahasa yang
\end{abstract}


mengakibatkan peminjaman bahasa. Penelitian ini adalah penelitian pustaka dengan metode deskriptif-kualitatif. Tulisan ini memaparkan pengaruh penyebaran Islam di Nusantara terhadap perkembangan bahasa Melayu (bahasa Indonesia). Hasil penelitian ini menunjukkan bahwa penyebaran agama Islam di Nusantara berpengaruh pada sistem aksara (abjad Jawi), bentuk serapan, bidang penyerapan, dan transliterasi ArabLatin.

Kata Kunci: penyebaran agama Islam; pengaruh; kontak bahasa; lingua franca; serapan

\section{Pendahuluan}

Penyebaran agama Islam di Nusantara melalui tiga metode sebagaimana dipaparkan oleh Graaf, yakni melalui perdagangan, pendakwah suci, dan politik. Penyebaran agama Islam melalui perdagangan dibawa oleh pedagang muslim dalam jalur perdagangan damai. Penyebaran agama Islam melalui para pendakwah dan para wali yang datang dari India atau Arab yang sengaja datang ke Nusantara dengan tujuan mengislamkan dan meningkatkan pengetahuan mereka yang telah beriman. Metode penyebaran agama Islam melalui politik, yakni dengan cara kekuasaan atau perang terhadap negara-negara penyembah berhala. ${ }^{1}$

Dari tiga metode seperti tersebut di atas, pendapat yang paling dominan adalah Islam disebarkan melalui perdagangan. Pendapat tersebut dipaparkan oleh Wertheim dan Pijnapel. ${ }^{2} \mathrm{Na}-$ mun, pendapat tersebut dibantah oleh van Leur ${ }^{3}$ dan Schrieke ${ }^{4}$. Menurutnya, penyebaran agama dengan metode perdagangan merupakan teori yang sangat lemah karena tidak mungkin

${ }^{1}$ H.J. De Graff, "Islam di Asia Tenggara sampai Abad ke-18" dalam Azyumardi Azra, Perspektif Islam di Asia Tenggara (Jakarta: Yayasan Obor Indonesia, 1989), hlm. 2.

${ }^{2}$ Nur Syam, Islam Pesisir (Yogyakarta: LkiS Pelangi Aksara), hlm. 63.

3 Taufik Abdullah, "Islam dan Pembentukan Tradisi di Asia Tenggara: Sebuah Perspektif Perbandingan" dalam Taufiq Abdullah dan Sharon Shiddiqui, Tradisi dan Kebangkitan Islam di Asia Tenggara(Jakarta: LP3ES, 1989), hlm. 29-30.

4 Azyumardi Azra, Jaringan Ulama Timur Tengah dan Kepulauan Nusantara Abad XVII dan XVIII (Bandung: Mizan, 1994), hlm. 32. 
Islamisasi dapat dilakukan secara besar-besaran oleh kaum pedagang dan perkawinan.

Terlepas dari perdebatan metode penyebaran Islam tersebut, penyebaran agama Islam di Nusantara tidak hanya berpengaruh pada perubahan sosial, tetapi juga pada perkembangan bahasa. Salah satu bahasa yang digunakan di wilayah Nusantara pada saat itu adalah bahasa Melayu yang merupakan sikal bakal lahirnya bahasa Indonesia. Bahasa Melayu mula-mula dipergunakan oleh penduduk yang mendiami daerah di sekitar Selatan Malaka. Selat ini sangat strategis sehingga sering dilalui kapal yang berlayar dari Asia Timur ke Asia Selatan atau sebaliknya. ${ }^{5}$

Bahasa Melayu memiliki peranan penting dalam memperlancar komunikasi antarpedagang di Selat Malaka. Oleh karena itu, bahasa Melayu disebut sebagai lingua franca. Linguafranca adalah sebuah istilah linguistik yang artinya "bahasa pengantar" atau "bahasa pergaulan" di suatu tempat yang penutur bahasanya yang berbeda-beda. Wardhaugh mendefinisikan lingua franca sebagai bahasa komunikasi yang biasa digunakan oleh masyarakat beda bahasa ibu. ${ }^{6}$ Lingua Franca adalah bahasa yang diangkat oleh para penutur yang berbeda budayanya untuk dipakai bersama-sama sebagai alat komunikasi. Misalnya, bahasa Arab di Timur Tengah, bahasa Latin di Eropa pada abad pertengahan, bahasa Melayu di Nusantara pada zaman kerajaan Siwijaya, dan bahasa Swahili di Afrika Tengah. ${ }^{7}$ Bahasa Arab berperan sebagai lingua franca terutama dalam penyebaran agama Islam. Bahasa Arab dan bahasa Melayu memiliki kedudukan yang sama, yakni sebagai lingua franca.

Tulisan ini mendeskripsikan pengaruh penyebaran Islam di Nusantara terhadap perkembangan bahasa Melayu. Penyebaran agama Islam di Nusantara mengakibatkan persentuhan bahasa, yakni kontak bahasa antara bahasa Arab dan bahasa Melayu. Hal ini melahirkan tata aksara atau abjad Jawi, yakni perpaduan

5 Ening Herniti, Sriharini, dan Navilah Abdullah, Bahasa Indonesia (Yogyakarta: Pokja Akademik UIN Sunan Kalijaga, 2005), hlm.

${ }^{6}$ Ronald Wardhaugh, An Introduction to Sociolinguistics (Oxford: Basil Blackwell, 1988), hlm. 59.

${ }^{7}$ Soeparno, Dasar-Dasar Linguistik Umum (Yogyakarta: Tiara Wacana, 2001), hlm. 77. 
tulisan Arab dengan penggunaan bahasa Melayu. Selain itu, hal yang tidak terelakan adalah adanya penyerapan dari fonem hingga kosakata bahasa Arab yang diserap ke dalam bahasa Melayu yang kemudian menjadi bahasa Indonesia. Penelitian ini adalah penelitian pustaka dengan metode kualitatif-deskriptif. Data diperoleh dari beberapa literatur penyebaran agama Islam dan buku-buku linguistik serta sosiolinguistik yang terkait dengan kontak bahasa.

\section{B. Agama Islam, Bahasa Arab, dan Bahasa Melayu (Bahasa Indonesia)}

Greertz menganggap agama merupakan bagian dari sistem kebudayaan. Ia melihat agama sebagai pola tindakan (pattern for behaviour), yakni sesuatu yang hidup dalam diri manusia yang tampak dalam kehidupan keseharian manusia. Agama adalah pedoman yang dijadikan sebagai kerangkan interpretasi tindakan manusia. ${ }^{8}$ Dalam menginterpretasikan tindakan manusia itu diperlukan alat komunikasi, yakni bahasa.

Hubungan antara agama Islam dan bahasa Arab seperti sekeping mata uang yang tidak terpisahkan. Bahasa Arab sebagai alat komunikasi memiliki peranan penting dalam penyebaran agama Islam karena dalam menyampaikan ajaran Islam tentunya menggunakan bahasa. Sementara itu, bahasa perhubungan yang dipakai di wilayah Nusantara pada saat itu adalah bahasa Melayu. Di sinilah terjadi kontak bahasa Arab dengan bahasa Melayu.

homason berpendapat bahwa kontak bahasa adalah peristiwa penggunaan lebih dari satu bahasa dalam tempat dan waktu yang sama. Penggunaan bahasa ini tidak menuntut penutur untuk berbicara dengan lancar sebagai dwibahasawan atau multibahasawan, tetapi terjadinya komunikasi antara penutur dua bahasa yang berbeda pun sudah dikategorikan sebagai peristiwa kontak bahasa. $^{9}$

8 Clifford Geertz, Kebudayaan dan Agama (Yogyakarta: Kanisius, 1992), hlm. 8-9.

9 Sarah Thomason. G, Language Contact (Edinburg: Edinburg University Press Ltd., 2001), hlm. 1. 
Peristiwa kontak bahasa ini mepresentasikan adanya keseimbangan yang melahirkan budaya campuran (acculturation). Hal ini terjadi karena dapat atau tidaknya suatu bangsa mempertahankan kebudayaannya bergantung pada pengaruh kebudayaan mana yang lebih kuat. Jika kebudayaan asli lebih kuat daripada kebudayaan asing, kebudayaan asli dapat bertahan. Namun, apabila kebudayaan asli lebih lemah dari kebudayaan asing, kebudayaan asli dapat lenyap.

Bahasa Arab dan bahasa Melayu memiliki kedudukan yang seimbang karena keduanya merupakan lingua franca. Bahasa Melayu digunakan oleh penduduk di Kepulauan Nusantara sejak 3000/2500 SM sampai dengan 500 M. Kemudian, bahasa Melayu menyebar dari timur di Pulau Pasifik ke barat di Madagaskar (Atlantik), dari utara di Formosa/Taiwan sampai ke selatan di Selandia Baru. ${ }^{10}$ Pada abad ke-7 M sampai dengan abad ke-14 M, bahasa Melayu digunakan oleh masyarakat di kerajaan Sriwijaya. Bahasa terus menyebar hingga Selat Malaka kisaran abad ke-15 sampai dengan abad ke-16. ${ }^{11}$

Bahasa Melayu telah mempertahankan kedudukannya sebagai bahasa yang paling berpengaruh di Asia Tenggara. Bahasa Melayu juga termasuk salah satu dari lima bahasa dunia yang mempunyai jumlah penutur terbesar. Ia merupakan bahasa nasional satu-satunya dari empat negara, yakni Brunei, Indonesia, Malaysia, dan Singapura. Jumlah penutur bahasa Melayu yang bermukim di Thailand adalah sejuta penutur lebih. Sementara itu, jumlah minoritas bermukim di Birma, Sri Langka, Australia, dan Belanda. Bahasa Melayu menjadi bahasa penunjang dalam pendidikan Islam di Kamboja dan Vietnam. Bahasa Melayu sebagai bahasa penghubung di ujung barat Papua New Guenia dan menjadi lambang tradisi komunitas Melayu di masyarakat Afrika Selatan. ${ }^{12}$

10 Suwardi dan Zulkarnain, Bahasa Melayu sebagai Lingua Franca, (Yogyakarta: Pustaka Pelajar, 2010), hlm.7.

${ }^{11}$ Ibid.

12 James T. Collins, Bahasa Melayu Bahasa Dunia(Jakarta: Yayasan Obor Indonesia, 2005), hlm.xvii. 
Pada sektor pendidikan, bahasa Melayu dipelajari di universitas di delapan negara Eropa, dua negara di Amerika Utara, Beijing, Bangkok, Kazakhstan, Osaka, Auckland, Pusan, Tasmania, dan Cebu City. Komunitas sarjana internasional yang mengkhususkan diri pada bahasa Melayu, yakni penduduk di Italia, Tanzania, Estonia, Israel, India, Republik Ceko, Swiss, Negeri Belanda, Rusia, Irlandia, Jerman, Taiwan, Finlandia, Thailand, dan Perancis serta ratusan sarjana Asia Tenggara yang mewakili 200 juta penutur bahasa Melayu di daerah mereka. ${ }^{13}$

Bahasa Melayu sebagai salah satu varian bahasa Austronesia Purba digunakan kurang lebih dua juta tahun yang lalu di Kalimantan Barat, ${ }^{14}$ Bahasa Austronesia Purba terbentuk di Taiwan. Penuturnya yang bekerja sebagai petani dan pengarung samudra bermigrasi ke arah selatan menuju dan melalui Filipina. Beberapa di antaranya ke timur untuk membangun kebudayaan manusia di pulau yang masih kosong dan tersebar di Kepulauan Pasifik. Sebagian lagi bermigrasi ke selatan dan barat untuk bertemu dengan manusia purba lain dan mendiami sepuluh ribu pulau di Kepulauan Asia Tenggara. Bahasa Melayu, yang terdiri dari 1000 bahasa, termasuk bahasa yang paling luas persebarannya di dunia karena digunakan dari pantai Afrika di Madagaskar sampai ke pulau-pulau di Amerika, di Rapanui (Pulau Paka, Cili), dari daerah pegunungan di Taiwan sampai ke puncak-puncak vulkanik yang bersalju di Selandaia Baru. ${ }^{15}$

Pada abad ke-15 berkembang bentuk yang dianggap sebagai bahasa Melayu klasik (classical Malay atau medieval Malay). Bentuk ini dipakai oleh Kesultanan Malaka, yang perkembangannya kelak disebut sebagai bahasa Melayu tinggi. Penggunaannya terbatas di kalangan keluarga kerajaan di sekitar Sumatera, Jawa, dan Semenanjung Malaya. Laporan Tome Pires, bangsa Portugis, menyebutkan adanya bahasa yang dipahami oleh semua pedagang di wilayah Sumatera dan Jawa. Magellan dilaporkan memiliki budak dari Nusantara yang menjadi juru

${ }^{13} \mathrm{Ibid}$.

${ }^{14}$ Ibid., hlm.4.

15 James T. Collins, Bahasa Melayu Bahasa Dunia(Jakarta: Yayasan Obor Indonesia, 2005), hlm.1. 
bahasa di wilayah itu. Ciri paling menonjol dalam ragam sejarah ini adalah mulai masuknya kata-kata pinjaman dari bahasa Arab dan bahasa Parsi, sebagai akibat dari penyebaran agama Islam yang mulai masuk sejak abad ke-12. Kata-kata bahasa Arab seperti masjid, kalbu, kitab, kursi, selamat, dan kertas, serta katakata Parsi seperti anggur, cambuk, dewan, saudagar, tamasya, dan tembakau masuk pada periode ini. Proses penyerapan dari bahasa Arab terus berlangsung hingga sekarang.

Pada pertengahan abad ke-19 terjadi terobosan penting ketika Raja Ali Haji dari istana Riau-Johor (pecahan Kesultanan Melaka) menulis kamus ekabahasa untuk bahasa Melayu. Sejak saat itu dapat dikatakan bahwa bahasa ini adalah bahasa yang full-fledged, sama tinggi dengan bahasa-bahasa internasional pada masa itu, karena memiliki kodifikasi. Kodifikasi ini sangat penting untuk menentukan status sebuah sistem linguistik. Sebagaimana dijelaskan oleh Wardhaugh bahwa sebuah sistem linguistik dapat disebut sebagai bahasa yang mandiri bila memiliki kriteria standardisasi. Standardisasi menunjukkan pada proses suatu bahasa dikodifikasikan yang meliputi pembuatan tata bahasa, kamus, dan kemungkinan literatur. ${ }^{16}$

Pada akhir abad ke-19 bahasa Melayu memiliki dua variasi, yakni Melayu pasar dan Melayu tinggi. Melayu pasar berupa bahasa kolokial dan tidak baku. Sementara itu, bahasa Melayu tinggi merupakan bahasa standar atau baku, tetapi terbatas pemakaiannya. Bahasa ini dapat dikatakan sebagai lingua franca, tetapi kebanyakan berstatus sebagai bahasa kedua atau ketiga. Bahasa Melayu ragam tinggi itulah yang kemudian diangkat menjadi bahasa Indonesia.

Bahasa Melayu diangkat menjadi bahasa Indonesia terjadi pada tanggal 28 Oktober 1928 atau yang dikenal dengan peristiwa Sumpah Pemuda. Dalam perkembangannya, bahasa Indonesia mulai ada kodifikasi dalam bidang perkamusan pada tahun 1988. Pembuatan kamus bahasa Indonesia mendapat sumbangan kosakata yang tidak sedikit dari bahasa Arab. Bahasa Arab sebagai bahasa sumber kedua setelah bahasa Sanskerta

${ }^{16}$ Ronald Wardhaugh, An Introduction to Sociolinguistics(Oxford: Basil Blackwell, 1988), hlm.33-34. 
dibawa ke Indonesia mulai abad ketujuh oleh saudagar dari Persia, India, dan Arab yang juga menjadi penyebar agama Islam. Sejak abad ke-12 bahasa Arab mulai mempengaruhi bahasa Melayu terutama sejak banyak raja yang mememeluk agama Islam. Bukti tertulis adanya unsur-unsur bahasa Arab yang masuk ke dalam bahasa Melayu adalah dengan ditemukan syair yang berbahasa Arab, bahasa Sanskerta, dan bahasa Melayu (bahasa Indonesia) di batu nisan di Minye Tujoh, Aceh, pada tahun $781 \mathrm{H}(1380 \mathrm{M}){ }^{17}$

Perkembangan kosakata bahasa Indonesia sangat pesat pada akhir abad ke-20 dan awal abad ke-21. Perkembangan kosakata tersebut dapat dilihat pada bertambahnya lema dalam kamus bahasa Indonesia dari satu edisi ke edisi berikutnya. Selama kurun waktu 20 tahun, Kamus Besar Bahasa Indonesia (KBBI) telah mengalami perkembangan muatan lema dari 62.000 lema pada edisi pertama (1988) hingga 91.000 lema pada edisi keempat (2008). ${ }^{18}$ Penambahan kosakata bahasa Arab dalam kosakata bahasa Indonesia tersebut menandakan bahwa bahasa Arab memiliki peranan yang cukup penting dalam penambahan perbendaharaan bahasa Indonesia.

\section{Pengaruh Islam pada Bahasa Melayu}

\section{Abjad Jawi}

Abjad Jawi (bahasa Arab: جوي Jăwi) (atau Yawi di daerah

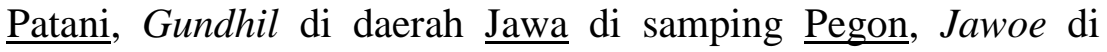
daerah Aceh) adalah abjad Arab yang dipakai untuk menuliskan bahasa Melayu. Abjad ini digunakan sebagai salah satu dari tulisan resmi di Brunei, dan juga di Malaysia, Indonesia, Patani, dan Singapura untuk keperluan religius. Abjad Jawi ini merupakan hasil akulturasi bahasa Arab dengan bahasa Melayu.

Kemunculan abjad Jawi berkaitan langsung dengan kedatangan agamaIslam ke Nusantara. Abjad ini didasarkan pada abjad Arab dan digunakan untuk menuliskan bahasa Melayu.

17 Ening Herniti, "Serapan Bahasa Asing dalam Bahasa Indonesia" dalam Jurnal SOSIO-RELIGIA, Vol. 5 No. 4, Agustus 2006.

18 Departemen Pendidikan Nasional, Kamus Besar Bahasa Indonesia (Jakarta: Balai Pustaka, 2012), hlm. xxix. 
Dengan demikian, tidak terhindarkan adanya tambahan atau modifikasi beberapa huruf untuk mengakomodasi bunyi yang tidak ada dalam bahasa Arab (misalnya, fonem /o/, /p/, atau /y/). Hal ini terjadi karena bahasa Arab memang tidak mengenal vokal /o/. Dalam bahasa Arab hanya dikenal vokal /a/, /i/, dan /u/. Dari sisi konsonan juga adanya penyesuaian seperti /c/, /p/, /ng/, /ny/, /g/, dan /v/. untuk lebih jelasnya berikut adalah penyesuaian huruf Arab dengan sistem penulisan Melayu.

\begin{tabular}{|c|c|c|c|c|}
\hline$e^{m}$ & ثtha & $=$ & $\Psi_{b a}$ & 3 oit \\
\hline$\dot{J}_{\text {deat }}$ & $>_{\text {dat }}$ & $\dot{\tau}$ tha & $\sum$ cha & $\tau^{n o}$ \\
\hline صshad & ش shin & & jza & J ra \\
\hline$\dot{\varepsilon}$ ghain & $\mathcal{E}_{\text {ain }}$ & $\dot{b}_{d z 0}$ & 1 tho & anad \\
\hline$\sigma_{\text {that }}$ & ق axt & $\Theta_{p a}^{a}$ & ف & $\sum_{\text {nog }}$ \\
\hline 9 маз & $\dot{ن}_{\text {nun }}$ & e mim & $J_{\text {iam }}$ & ${ }^{3}$ \\
\hline \multirow[t]{2}{*}{ ي } & s hamzan & $Y_{\text {lam ant }}$ & otha & ; va \\
\hline & & & & (3) mes \\
\hline
\end{tabular}

Pemakaian abjad atau tulisan Jawi masih sampai sekarang masih dipertahankan di Pesantren, biasanya digunakan untuk memaknai kitab kuning.

\section{Bentuk Serapan dari Bahasa Arab}

Bahasa Arab terus berkembang dan menyebar ke luar jazirah Arab seiring dengan menyebarnya agama Islam. Bahasa Arab juga menjadi simbol nasionalisme Arab ketika Islam mulai menyebar ke berbagai wilayah. Dari berbagai suku dan kabilah, bahkan bangsa yang berbeda, kemudian disatukan oleh bahasa Arab. Dengan demikian, bahasa Arab menjadi identitas bangsa Arab. Kenyataan tersebut mendorong dirumuskannya bahasa Arab baku yang harus disepakati sebagai lingua franca. ${ }^{19}$

19 Tim Penyusun, Ensiklopedi Islam, Vol. 4 (Jakarta: PT. Ikhtiar Baru Van Hoeve, 1993), hlm. 2-4 
Bahasa Arab sebagai salah satu bahasa sumber dibawa ke Indonesia mulai abad ke-7 oleh saudagar dari Persia, India, dan Arab yang juga menjadi penyebar agama Islam. Sejak abad ke12 bahasa Arab mulai memengaruhi bahasa Melayu terutama sejak banyak raja yang mememeluk agama Islam. Bukti tertulis adanya unsur-unsur bahasa Arab yang masuk ke dalam bahasa Melayu adalah dengan ditemukan syair yang berbahasa Arab, bahasa Sanskerta, dan bahasa Melayu (bahasa Indonesia) di batu nisan di Minye Tujoh, Aceh pada tahun 781 H (1380 M).

Setelah agama Islam masuk ke Indonesia, banyak cerita Melayu disalin dengan huruf Arab. Pada saat itu karya sastra umumnya ditulis dengan huruf Arab dan menggunakan bahasa Melayu. Keadaan seperti ini memudahkan masuknya unsur bahasa Arab ke bahasa Melayu. Di samping itu, ukuran sebuah karya sastra dianggap bermutu atau tidak adalah adanya bahasa Arab dalam karyanya. Semakin banyak unsur-unsur bahasa Arab ada dalam karyanya, semakin bermutu karyanya. ${ }^{20}$

Unsur serapan bahasa Arab dalam bahasa Indonesia berupa fonem, afiks, dan kata. Unsur serapan yang berupa fonem adalah $f, q, z, k h$, dan sy. Fonem-fonem tersebut terserap dalam bahasa Indonesia bersamaan dengan kata yang mengandung fonem tersebut, seperti fonem $f$ pada fakir, kafan, maaf, furqan, fonem $q$ pada kata Quran, fonem $z$ pada kata zakat, lazim, juz, zaman, zina, dan izin, fonem $k h$ pada khusus, akhir, fonem sy pada syarat, isyarat, syair, dan musyawarah.

Unsur serapan dari bahasa Arab yang berupa kata seperti kata abad, adab, adat, adil, ahad, ahli, akal, akhir, akrab, alam, almarhum, amal, aman, arwah, asyik, awal, ayat, bab, bandar, daftar, derajat, doa, dunia, edar, fasik, gaib, gairah, hadiah, hadir, hak, hakikat, hakim, hal, hamil, hasil, hasrat, hayat, hemat, heran, hewan, hormat, hukum, ibarat, iklim, ikrar, iman, jamak, jilid, jumat, kabar, kalimat, kamis, kamus, kemah, kisah, kitab, kursi, maaf, majelis, majemuk, makhluk, maut, misal, mimbar, mufakat, musyawarah, perlu, paham, Rabu, saat, Sabtu, Sekedar,

${ }^{20}$ Nyoman Tusthi Eddy, Unsur SerapanBahasa Asing dalam Bahasa Indonesia(Flores: Nusa Indah, 1989), hlm. 17. 
sejarah, selamat, Selasa, Senin, syarat, taat, umur, waktu, wajah, yakin, zaman, dan lain-lain.

Selain berupa kata, bahasa Indonesia juga menyerap afiks yang berupa sufiks $-i$, -wi, dan $-i a h$. Arti sufiks $-i /$-wi adalah mempunyai sifat. Perbedaan antara sufiks $-i$-wi adalah sufiks $-i$ melekat pada kata dasar yang berakhir dengan konsonan, missalnya alami, badani, duniawi, hewani, insani, dan maknawi. Sufiks -iah (dalam bahasa Arab -iyyah) memiliki arti yang sama dengan sufiks -i/-wi. Jadi, kata alamisama dengan alamiah. Hanya saja yang membedakan keduanya adalah nuansa kata alamiah lebih menunjukkan kekhasan sifat yang ditunjuk.

\section{Bidang Penyerapan}

Penyerapan bahasa Arab dalam bahasa Indonesia hampir masuk ke semua bidang. Taylor mencatat sekitar $15 \%$ dari kosakata bahasa Melayu merupakan adaptasi bahasa Arab. ${ }^{21}$

\section{a. Keagamaan Islam/Peribadatan}

Penyerapan bahasa Arab ke dalam bahasa Indonesia didominasi dalam ranah peribadatan seperti pada beberapa istilah dalam salat, puasa, zakat, haji, pernikahan, dan warisan.

\section{b. Istilah dalam Ekonomi}

Penelitian yang dilakukan M. Musyafa' menunjukkan bahwa adanya beberapa istilah dalam bidang ekonomi Islam yang diserap dan dipinjam dari bahasa Arab, seperti istilah akad, hak, ijarah, kabul, murabahah, musyarakah, salam dan istishna, riba, muzara'ah, mudarabah, mudarib, dan gharar. ${ }^{22}$ Hal ini menunjukkan bahwa penyebaran agama Islam juga berpengaruh pada bidang perekonomian di Indonesia hingga saat ini.

${ }^{21}$ Jean Gelman Taylor, Indonesia: Peoples and Histories (New Haven: Yale University Press, 2003), hlm. 105.

${ }^{22}$ M. Musyafa, "Istilah-Istilah dalam Ekonomi Islam: Upaya Memperkaya Khazanah Kosakata Bahasa Indonesia" dalam Jurnal Dialektika, Vo. 2 No. 2 Desember 2015, hlm. 140-150. 


\section{c. Istilah dalam bidang Politik}

Islam terus menguat menjadi kekuatan institusi politik yang mengemban ajaran dan syariat Islam. Pengaruh penyebaran Islam di bidang politik di Nusantara antara lain istilah dalam sistem pemerintahan yang berbentuk kerajaan berubah namanya menjadi kesultanan, seperti penggunaan istilah raja berganti gelar menjadi sultan. Istilah sultan dari bahasa Arab سلطان yang berarti "raja", "penguasa", "keterangan" atau "dalil". Sultan kemudian dijadikan sebutan untuk seorang raja atau pemimpin muslim, yang memiliki suatu wilayah kedaulatan penuh yang disebut kesultanan (bahasa Arab: سلطنة, sulthanatun). Gelar sultan kali pertama digunakan di Nusantara oleh Sultan Malik As-Saleh, Kesultanan Pasai.

\section{d. Pengkalenderan}

Akulturasi Islam dalam bidang pengkalenderan di Nusantara adalah sistem kalender yang diciptakan oleh Sultan Agung. Ia melakukan beberapa perubahan pada penamaan bulan. Penyebutan nama bulan mengacu pada bahasa Arab seperti Sura (Muharram atau Assyura dalam Syiah), Sapar (Safar), Mulud (Rabi'ul Awal), Bakda Mulud (Rabi'ul Akhir), Jumadilawal (Jumadil Awal), Jumadilakir (Jumadil Akhir), Rejeb (Rajab), Ruwah (Sya'ban), Pasa (Ramadhan), Sawal (Syawal), Sela (Dzulqaidah), dan Besar (Dzulhijjah). Kalender tersebut dimulai tanggal 1 Muharam tahun $1043 \mathrm{H}$. Kalender Sultan Agung dimulai tepat dengan tanggal 1 Sura tahun 1555 Jawa (8 Agustus 1633). Di samping itu, penamaan hari juga dipengaruhi oleh bahasa Arab, yakni hari Senin, Selasa, Rabu, Kamis, Jumat, Sabtu, dan Ahad.

\section{Transliterasi Arab-Latin}

Menurut Kamus Besar Bahasa Indonesia, trasliterasi adalah penyalinan dengan penggantian huruf dari abjad yang satu ke abjad yang lain. Transliterasi Arab-Latin ialah penyalinan hurufhuruf Arab dengan huruf-huruf Latin beserta perangkatnya. ${ }^{23}$

${ }^{23}$ Depdiknas, Kamus Besar Bahasa Indonesia (Jakarta: Balai Pustaka, 2012), hlm. 1071. 
Gagasan pembakuan transliterasi Arab-Latin bermula dari hasil seminar pada tahun 1985/1986. Seminar itu juga membentuk tim yang bertugas merumuskan hasil seminar yang akan dibahas dalam seminar nasional Pembakuan Trasliterasi ArabLatin 1985/1986. Tim ini terdiri dari H. Sawabi Ihsan, M.A., Ali Audah, Prof. Gazali Dunia, Prof. Dr. H.B. Jassin, dan Drs. Sudarno, M.Ed.. ${ }^{24}$

Pembakuan pedoman Trasliterasi Arab-Latin dengan memperhatikan tiga prinsip, yaitu (1) sejalan dengan Ejaan yang Disempurnakan (EYD), mulai tahun 2015 menjadi Ejaan Bahasa Indonesia (EBI), (2) huruf Arab yang belum ada padanannya dalam huruf Latin dicarikan padanan dengan cara memberi tambahan tanda diakritik, dengan dasar "satu fonem satu huruf", dan (3) pedoman trasnliterasi diperuntukan bagi masyarakat umum. $^{25}$

Transliterasi huruf Arab ke dalam huruf Latin berdasarkan pada Surat Keputusan Bersama (SKB) Menteri Agama Republik Indonesia dan Menteri Pendidikan dan Kebudayaan Republik Indonesia Nomor 158 Tahun 1987 dan Nomor 0543 b/U/1987. Pedoman transliterasi Arab-Latin sangat dibutuhkan oleh masyarakat Indonesia yang beragama Islam, terutama yang tidak dapat membaca tulisan Arab. Adanya SKB tersebut membuktikan pengaruh Islam di Indonesia sangat kuat.

\section{Simpulan}

Penyebaran agama Islam di Nusantara berpengaruh pada perkembangan bahasa Melayu (bahasa Indonesia). Hal ini terjadi karena hubungan antara agama Islam dan bahasa Arab seperti sekeping mata uang yang tidak terpisahkan. Bahasa Arab sebagai alat komunikasi memiliki peranan penting dalam penyebaran agama Islam. Sementara itu, bahasa perhubungan yang dipakai di wilayah Nusantara pada saat itu adalah bahasa Melayu. Bahasa Melayu menjadi lingua franca karena memiliki peranan penting

${ }^{24}$ Depag RI, Pedoman Transliterasi Arab-Latin(Jakarta: Badan Litbang Agama dan Diklat Keagamaan, 2003), hlm.1.

${ }^{25}$ Depag RI, Pedoman Transliterasi Arab-Latin(Jakarta: Badan Litbang Agama dan Diklat Keagamaan, 2003), hlm. 3. 
dalam memperlancar komunikasi antarpedagang di Selat Malaka. Bahasa Arab juga menjadi lingua franca terutama dalam penyebaran agama Islam. Oleh karena itu, bahasa Arab dan bahasa Melayu memiliki kedudukan yang seimbang karena keduanya merupakan lingua franca. Keseimbangan ini dipresentasikan dengan adanya percampuran dua bahasa.

Pengaruh penyebaran agama Islam pada perkembangan bahasa Melayu (bahasa Indonesia) melahirkan abjad Jawi (bahasa Arab: جوي Jăwi) (atau Yawi di daerah Patani, Gundhil di daerah Jawa di samping Pegon, Jawoe di daerah Aceh). Abjad Jawi adalah abjad Arab yang digunakan untuk menuliskan bahasa Melayu. Pengaruh lainnya adalah adanya unsur serapan, yakni fonem, imbuhan, kosakata, dan istilah-istilah dalam bidang keagamaan, politik, ekonomi, dan pengkalenderan. Pengaruh yang tidak kalah pentingnya adalah terbitnya Surat Keputusan Bersama Menteri Agama Republik Indonesia dan Menteri Pendidikan dan Kebudayaan Republik Indonesia Nomor 158 Tahun 1987 dan Nomor 0543 b/U/1987 tentang Pedoman Transliterasi Huruf Arab ke dalam Huruf Latin.

\section{Daftar Pustaka}

Abdullah, "Islam dan Pembentukan Tradisi di Asia Tenggara: Sebuah Perspektif Perbandingan" dalam Taufiq Abdullah dan Sharon Shiddiqui, Tradisi dan Kebangkitan Islam di Asia Tenggara, Jakarta: LP3ES, 1989.

Azra, Azyumardi, Jaringan Ulama Timur Tengah dan Kepulauan Nusantara Abad XVII dan XVIII, Bandung: Mizan, 1994.

Collins, James T., Bahasa Melayu Bahasa Dunia, Jakarta: Yayasan Obor Indonesia, 2005.

Depag RI, Pedoman Transliterasi Arab-Latin, Jakarta: Badan Litbang Agama dan Diklat Keagamaan.

Departemen Pendidikan Nasional, Kamus Besar Bahasa Indonesia, Jakarta: Balai Pustaka, 2012. 
Depdiknas, Kamus Besar Bahasa Indonesia, Jakarta: Balai Pustaka, 2012.

Eddy, Nyoman Tusthi, Unsur Serapan Bahasa Asing dalam Bahasa Indonesia, Flores: Nusa Indah, 1989.

Geertz, Clifford, Kebudayaan dan Agama, Yogyakarta: Kanisius, 1992.

Graff, H.J. De. "Islam di Asia Tenggara sampai Abad ke-18" dalam Azyumardi Azra, Perspektif Islam di Asia Tenggara, Jakarta: Yayasan Obor Indonesia, 1989.

Herniti, Ening, "Serapan Bahasa Asing dalam Bahasa Indonesia" dalam Jurnal SOSIO-RELIGIA, Vol. 5 No. 4, Agustus 2006.

Herniti, Ening, Sriharini, dan Navilah Abdullah, Bahasa Indonesia, Yogyakarta: Pokja Akademik UIN Sunan Kalijaga, 2005.

Musyafa, M., "Istilah-Istilah dalam Ekonomi Islam: Upaya Memperkaya Khazanah Kosakata Bahasa Indonesia" dalam Jurnal Dialektika, Vo. 2 No. 2 Desember 2015, hlm. 140-150.

Soeparno, Dasar-Dasar Linguistik Umum, Yogyakarta: Tiara Wacana, 2001.

Suwardi dan Zulkarnain, Bahasa Melayu sebagai Lingua Franca, Yogyakarta: Pustaka Pelajar, 2010.

Syam, Nur, Islam Pesisir, Yogyakarta: LkiS Pelangi Aksara, 2005.

Taylor,Jean Gelman, Indonesia: Peoples and Histories, New Haven: Yale University Press, 2003.

Thomason. G, Sarah, Language Contact, Edinburg: Edinburg University Press Ltd., 2001.

Tim Penyusun, Ensiklopedi Islam, Vol. 4, Jakarta: PT. Ikhtiar Baru Van Hoeve, 1993.

Wardhaugh, Ronald, An Introduction to Sociolinguistics, Oxford: Basil Blackwell, 1988. 
Jurnal Lektur Keagamaan, Vol. 15, No. 1, 2017: 81-96 